\title{
STRATEGI COMMUNITY PRACTICE DALAM PENGEMBANGAN PARIWISATA BERBASIS MASYARAKAT
}

\author{
Oleh: \\ Dr.Risna Resnawaty, S.Sos., M.P
}

\begin{abstract}
ABSTRAK
Industri pariwisata merupakan salah satu sektor yang dapat membantu meningkatkan kesejahteraan masyarakat. Industri pariwisata mendorong tumbuhnya ekonomi produktif di masyarakat. Industry pariwisata membuka peluang bagi masyarakat untuk melakukan berbagai jenis usaha seperti usaha penginapan, katering, kerajinan, dan lainnya. Pengelolaan pariwisata yang baik adalah ketika sektor pariwisata dapat memberikan manfaat bagi seluruh masyarakat. Hal tersebut dapat dilihat ketika usaha-usaha kecil yang ada di masyarakat ikut dilibatkan dalam industri pariwisata. Kepulauan Seribu memiliki tiga karakteristik khusus sebagai daerah wisata pantai yang menjadi daya tarik bagi wisatawan untuk datang berkunjung. Ketiga karakteristik wisata ini antara lain wisata pantai (pulau wisata umum) berjumlah 45 pulau, wisata cagar alam berjumlah 2 (dua) pulau dan wisata sejarah berjumlah 4 (empat) pulau. Dari keseluruhan pulau terdapat 11 pulau wisata yang merupakan pulau permukiman. Salah satu pulau yang menjadi objek wisata favorite di kepulauan Seribu adalah Pulau Tidung. Pulau Tidung merupakan salah satu pulau pemukiman yang memiliki potensi alam yang dapat menjadi daya tarik bagi wisatawan. Potensi tersebut merupakan aset yang dimiliki oleh masyarakat Pulau Tidung, yang apabila dikembangkan akan dapat mendorong peningkatan kesejahteraan masyarakat. Diawali dengan kebijakan pemerintah pusat yang kemudian diimplementasikan dalam kegiatan pengembangan pariwisata berhasil mendorong pulau Tidung sebagai salah satu tujuan wisata utama di Kepulauan Seribu. Dalam proses pengembangan pariwisata ini Masyarakat Pulau Tidung turut bergerak aktif sebagai pelaku utama dari perubahan yang awalnya masyarakt nelayan menjadi masyarakat pariwisata. Kesadaran masyarakat untuk turut berkontribusi dalam pengembangan pariwisata didukung dengan langkah-langkah strategis dalam mengembangkan keterampilan dan mengembangkan jejaring untuk mendukung kemajuan pariwisata Pulau Tidung, serta keterlibatan antar actor.
\end{abstract}

Keywords: community practice, community development, community based tourism

\section{Latar Belakang Penelitian}

Pengembangan usaha-usaha kecil di masyarakat yang berkaitan dengan industri pariwisata menjadi salah satu strategi untuk mensejahterakan masyarakat yang bertujuan untuk mendukung pembangunan ekonomi nasional. Usaha perekonomian merupakan aset yang ada di masyarakat atau komunitas.
Dalam pengembangan sektor wisata ini diperlukan intervensi khusus yang dilakukan secara bersama-sama baik oleh pemerintah beserta masyarakat guna pencapaian tujuan peningkatan kesejahteraan masyarakat. Glen (1993) menyebutkan bahwa pencapaian tujuan bersama harus dilakukan secara terintegrasi melibatkan semua komponen di 
dalam masyarakat termasuk pemerintah dan kelembagaan terkait, yang disebut sebagai praktik bersama komunitas (community practice). Salah satu bentuk community practice adalah community development (pengembangan masyarakat). Pengembangan masyarakat dapat dipandang sebagai usaha yang terencana untuk membangun aset yang meningkatkan kapasitas penghuni untuk memperbaiki kualitas hidup mereka (Green and Haines, 2002:8). Sedangkan, Kretzmann and McKnight (1993:25) mendefinisikan aset sebagai bakat, keterampilan, dan kapasitas dari individual, asosiasi, dan institusi dalam suatu komunitas. Lima tipe aset yaitu fisik, manusia, sosial, finansial, dan lingkungan. Namun lebih lanjut dari pengembangan usaha ekonomi, pengembangan masyarakat juga berbicara mengenai bagaimana perubahan masyarakat menjadi masyarakat yang memiliki kapasitas untuk menghadapi berbagai perubahan atas perkembangan industri wisata di daerahnya.

Pengembangan masyarakat pada dasarnya dapat dibedakan menjadi dua kategori yaitu pengembangan tempat (place) dan pengembangan orang (people). Pengembangan masyarakat yang berfokus pada people akan berupaya untuk meningkatkan kapasitas setiap individu yang ada di wilayah miskin. Namun, setelah kapasitas individu meningkat, apakah ada jaminan akan lapangan pekerjaan di wilayah miskin tersebut. Akibatnya individu yang sukses (dengan kemampuan yang meningkat) akan berpotensi meninggalkan wilayah miskin tersebut untuk mencari lapangan kerja yang lebih menjanjikan di wilayah yang baru. Sedangkan, pengembangan masyarakat yang memfokuskan kepada place, memungkinkan komunitas untuk dapat menawarkan investasi baru di wilayah mereka.

\section{Perumusan Masalah}

Kepulauan Seribu merupakan ditetapkan sebagai Kabupaten Administratif di wilayah Provinsi DKI Jakarta sejak tahun 2001. Sejak saat itu, pemerintah kabupaten aktif dalam melakukan pembangunan di Kepulauan Seribu. Salah satu sasaran pembangunan di Kepulauan Seribu tersebut adalah pengembangan pariwisata. Dari 110 pulau yang berada di wilayah administratif Kabupaten Seribu, Pulau Tidung merupakan salah satu pulau yang dikembangkan untuk menjadi sasaran wisata.

Pulau Tidung merupakan destinasi utama kunjungan wisata di Kepulauan seribu, karena semakin banyaknya wisatawan yang berkunjung di Pulau Untung Jawa menjadikan Pulau Tidung tujuan utama para pecinta laut yang tidak terlalu suka dengan keramaian, walaupun jarak yang cukup jauh dari daratan Jakarta. Kegiatan yang diberikan oleh Pulau Tidung ialah memancing dan berenang. Adanya dermaga yang terdapat di Pulau Tidung digunakan sebagai tempat untuk memancing, selain juga disediakan kapal 
untuk disewa ke tengah laut. Selain itu kegiatan berenang, snorkeling serta diving juga menjadi daya tarik di Pulau ini. Daya tarik lainnya yaitu pada pulau ini terdapat jembatan yang menghubungkan Pulau Tidung Besar dengan Pulau Tidung Kecil, sehingga pada lokasi ini sering dijadikan lokasi untuk foto karena keindahannya.

Pengembangan pariwisata di Pulau Tidung tersebut tidak hanya dilakukan oleh pemerintah, akan tetapi juga melibatkan masyarakat secara penuh dalam proses tersebut. Masyarakat dipandang sebagai aktor utama dalam pengembangan pariwisata, pemerintah mendukung hal tersebut dengan berbagai regulasi yang mengatur dan melindungi kepentingan dari masyarakat. Pemusatan pada masyarakat tersebut menunjukkan bahwa pengembangan pariwisata dapat dilakukan dengan menerapkan strategi praktik bersama komunitas (community practice).

Melihat pada hal tersebut, akan dilihat mengenai bagaimana strategi community practice dalam pengembangan pariwisata di Pulau Tidung yang dilakukan oleh Pemerintah Daerah Kabupaten Pulau Seribu.

\section{Community Practice dan Community Development \\ Istilah

$$
\text { community }
$$

practice

dipopulerkan oleh Banks, Buctcher,

Henderson, dan Robertson (2003).

Penekanannya terminologi ini seperti dikemukakan oleh Banks adalah bahwa community practice memiliki cakupan lebih luas dari community development ataupun community work. Thornton (1996) dalam Butcher (2003) mengemukakan:

In essence a distinction was made between community development as a specific set of skills, community work as professional discipline and community practice - the latter being a wider practice that draws on community development and may employ community workers, but in neither case exclusively. Other professions would also have an interest in community practice, and skills other than community development might be used (p.3)

Glen (1993) menjelaskan bahwa community development merupakan salah satu strategi dari community practice (praktek dalam mengembangkan masyarakat). Pendekatan community development di masa lalu seringkali dijadikan sebagai acuan dalam usaha paska perang dunia II atau masa postjaman penjajahan oleh Inggris. Pada masa itu pendekatan community development digunakan oleh badan-badan internasional untuk meningkatkan kondisi sosial dan ekonomi di negara-negara bekas jajahan dengan kewenangan pemerintah. Namun pada masa kini pengertian mengenai community development telah berkembang menjadi pendekatan yang mengedepankan otoritas masyarakat lokal dalam menentukan orientasi dan masa depan hidupnya, memotivasi berkembangnya sektor volunteer dalam mempromosikan pembangunan sosial. 
Community development dapat dilihat sebagai usaha untuk menterjemahkan gaya paternalistik dalam meningkatkan penentuan nasib dari komunitas lokal sekaligus juga menumbuhkan kemandirian pada diri masyarakat terutama di negara berkembang agar mereka mampu terjun dalam cara-cara demokrasi yang positif mengenai "di mana posisi manusia" dalam masyarakat industri (urban) yang merupakan masyarakat multi kultur. Pendekatan community development ini memiliki karakteristik utama yaitu:

- Usaha yang dilakukan untuk masyarakat dengan tujuan mendefinisikan kebutuhan pribadi masyarakat dan mengkondisikan masyarakat.

- Proses yang dilakukan meliputi pengembangan jaringan yang kreatif dan kooperatif antar manusia dan kelompok-kelompok dalam masyarakat.

- Akan selalu melibatkan praktisi komunitas yang memiliki keterampilan mengoperasikan secara tidak langsung.

\section{METODOLOGI PENELITIAN}

Penelitian ini menggunakan pendekatan kualitatif, merujuk pada penjelasan Creswell (2002: 4) tentang asumsi pendekatan kualitatif dengan mempertimbangkan realitas subyektif yang dianut oleh obyek penelitian, dalam hal ini strategi community practice dalam pengembangan pariwisata di Pulau Tidung. Pemilihan pendekatan kualitatif digunakan untuk mencari informasi yang mendalam tentang praktik pengembangan masyarakat yang dilakukan oleh pemerintah Kabupaten Administrif Kepulauan Seribu.
Informasi yang mendalam mengenai strategi community practice tersebut dilihat dari pelibatan masyarakat dalam pengembangan pariwisata yang didukung oleh kebijakan pemerintah daerah. Pemahaman mengenai pelibatan masyarakat tersebut kemudian dimaknai sehingga memperoleh data kualitatif mengenai strategi community practice.

Penelitian ini merupakan penelitian deskriptif seperti yang dikemukakan oleh Neuman (2006:35) bahwa descriptive research presents a picture of the spesific details of a situation, social setting, or relationship...descriptive study presents a picture of types of people or of social activities". Penelitian ini mendeskripsikan mengenai strategi community practice dalam pengembangan pariwisata, yang dilakukan oleh pemerintah daerah administratif Kabupaten Kepulauan Seribu. Strategi tersebut dilihat dari kebijakan pemerintah daerah dan pelibatan masyarakat dalam pengembangan pariwisata daerah.

Untuk memperoleh data yang utuh, proses pengumpulan data baik itu observasi, studi dokumentasi dan indepth interview menggunakan landasan waktu tersebut untuk mempelajari dan mengetahui fenomena pengembangan pariwisata di Pulau Tidung. Pengumpulan data dilakukan menggunakan beberapa teknik, yaitu: 1) Pengamatan (observasi) mengenai pariwisata yang ada di Pulau Tidung. Observasi pada programprogram pelayanan yang sudah dilaksanakan oleh Pemerintah Kabupaten Administratif Kepulauan Seribu. 2) Indepth Interview, 
informasi yang mendalam mengenai strategi community practice dalam pengembangan pariwisata di Pulau Tidung. Wawancara mendalam terhadap 3 orang pemerintah daerah. Informasi yang didapatkan mengenai kebijakan yang dikeluarkan oleh dengan pengembangan pariwisata, serta pelibatan masyarakat dalam pengembangan pariwisata. Sementara jumlah tokoh informal yang dijadikan informan sejumlah 8 informan yang terdiri dari nelayan, tokoh pemuda, pelaku usaha, dan wisatawan.

Penelitian ini dilakukan di Pulau Tidung, Kabupaten Administratif Kepulauan Seribu Provinsi DKI Jakarta. Pulau Tidung merupakan salah satu pulau berpenghuni yang ada di Kepulauan Seribu. Pulau tersebut sejak tahun 2008 ditetapkan sebagai salah satu kawasan wisata di Kepulauan Seribu. Karakter tersebut menjadi khas ketika masyarakat di Pulau Tidung, yang sebelumnya merupakan masyarakat nelayan, berubah menjadi masyarakat wisata. Waktu yang dipergunakan untuk melakukan penelitian strategi community practice dalam pengembangan pariwisata di Pulau Tidung ini adalah selama 5 bulan

\section{Strategi Community Practice dalam Pengembangan Pariwisata}

Pengembangan kawasan wisata merupakan salah satu strategi yang dilakukan oleh pemerintah untuk meningkatkan pendapatan daerah. Strategi ini umumnya diterapkan oleh daerah-daerah yang memiliki sumber daya alam yang dapat menjadi daya tarik wisata. Di Indonesia, banyak daerah yang memiliki potensi alam yang indah dan telah dikembangkan menjadi objek wisata yang diandalkan oleh pemerintah daerah. Salah satu daerah yang mengembangkan sumber daya alamnya menjadi objek wisata adalah pemerintah provinsi DKI Jakarta. Salah satu sumber daya alam yang dikembangkan menjadi objek wisata oleh Pemprov DKI adalah Kepulauan Seribu. Kepulauan Seribu merupakan gugusan pulau yang berada di sebelah utara wilayah DKI Jakarta, dan terdiri dari 342 pulau dan 11 di antaranya merupakan pulau yang berpenghuni. Dengan berbagai potensi yang ada, pengembangan kawasan wisata menjadi kunci utama yang dilakukan pemerintah daerah dalam membangun daerah Kepulauan Seribu ini.

Pengembangan wisata Pulau Tidung dapat dieskripsikan dalam tiga proses kegiatan besar antara lain mendefinisikan kebutuhan dan mengkondisikan masyarakat, pembentukan jaringan kreatif, dan pelibatan praktisi yang turut memiliki kontribusi dalam proses pengembangan wisata.

\section{Sebuah Langkah Awal: Mendefinisikan Kebutuhan dan Pengkondisian Masyarakat Pada awalnya wisata pulau Tidung} maupun pulau-pulau penduduk di Kepulauan Seribu belum terorganisir dengan baik, setiap usaha berdiri sendiri-sendiri, sampah bertebaran, pola hidup tidak teratur, dan masyarakat malas untuk menjaga kebersihan 
wilayahnya. Hal ini disebabkan masyarakat belum memahami pentingnya menjaga aset pantai, dan belum memahami potensi wisata yang mereka miliki. Salah seorang penduduk yang sekarang menjadi penggiat pariwisata di Pulau Tidung menyatakan bahwa pada tahun 1990-an wisatawan belum banyak yang datang. Jika ada wisatawan yang datang mereka tidak banyak merasakan dampak yang signifikan dalam pendapatan mereka, selain masyarakat yang memiliki usaha menyewakan rumahnya untuk penginapan.

Melihat potensi pemandangan yang sangat indah dan air laut yang jernih di pantai Pulau Tidung, seiring dengan komitmen pemerintah untuk mengembangkan Kepulauan Seribu sebagai destinasi Wisata terbaik di Indonesia, pemerintah mulai serius untuk mengembangkan wilayah pariwisata termasuk di Pulau Tidung.

Pemerintah Kepulauan seribu menyadari bahwa Pulau-pulau yang mereka miliki merupakan aset yang dapat dikembangkan untuk menarik wisatawan. Sebenarnya Kepulauan seribu telah dikenal menjadi destinasi wisata bagi turis domestik maupun asing sejak tahun 1980an. Dalam kesehariannya masyarakat telah terbiasa dengan keberadaan turis di tengah-tengah masyarakat mereka. namun pada masa 1980 hingga 1990-an belum semua masyarakat memahami potensi alam yang mereka miliki dan mampu menjadikan hal tersebut sebagai aset yang dapat meningkatkan kesejahteraan bagi mereka.

Proses pengkondisian masyarakat mulai dilakukan pada awal tahun 2000an. Masyarakat Pulau Tidung menyatakan bahwa pada awalnya pihak pemerintah mulai mendatangi beberapa pelaku usaha di bidang pariwisata yang ada di pulau Tidung. Upaya untuk mengembangkan pariwisata berbasis masyarakat tentu harus melibatkan masyarakat yang tinggal di kepulauan tersebut. Langkah awal yang dilakukan untuk mengembangkan pariwisata dimulai dengan memahami potensi yang dimiliki oleh masyarakat Pulau Tidung baik potensi alam maupun sumber daya manusia yang ada. Dengan adanya sosialisasi pemerintah mengenai visi dan misi Kepulauan Seribu, masyarakat Pulau Tidung lambat laum memahami bahwa mereka memiliki potensi alam yang sangat indah yang mampu menarik wisatawan untuk datang. Setelah masyarakat memahami potensi yang mereka miliki, pemerintah menganjurkan kepada masyarakat setempat untuk menjaga kebersihan kawasan mereka. Upaya yang dilakukan adalah dengan menanamkan pemikiran: "pantai yang bersih akan memberikan berkah yang banyak. Jika pantai tidak terjaga maka wisatawan akan enggan datang sehingga rezeki (uang) akan sulit untuk datang."

Pemerintah Kabupaten Kepulauan Seribu maupun pemerintah Pulau Tidung menyatakan bahwa untuk mengajak masyarakat memahami korelasi antara 
kebersihan dan pengembangan wisata pantai bukan merupakan hal yang mudah. Pada awalnya masyarakat setempat masih menganggap bahwa kewajiban untuk menjaga kebersihan pantai hanya kewajiban bagi para pelaku usaha pariwisata. Namun pemerintah tak hentinya melakukan penyadaran pada masyarakat setempat lewat sosialisasi secara formal di kelurahan maupun secara informal dari mulut ke mulut. Bahwa pulau Tidung ini secara keseluruhan merupakan aset wisata yang dapat memperbaiki kondisi ekonomi masyarakat.

Upaya untuk mendefinisikan kebutuhan masyarakat ini mulai menemukan titik temu dengan adanya penyadaran dari pemerintah mengenai korelasi menjaga lingkungan dengan peningkatan pendapatan. Masyarakat menyadari bahwa ada kepentingan yang sama-sama mereka rasakan yaitu keinginan meningkatkan kualitas hidup mereka. masyarakat mulai menyadari bahwa jika seluruh warga di wilayah mereka hanya mengandalkan pendapatan sebagai nelayan maka kehidupan mereka akan stagnan. Atas kesadaran tersebut masyarakat kemudian menerima konsep-konsep pariwisata yang disosialisasikan pemerintah Kepulauan Seribu. Masyarakat merasakan bahwa mereka butuh akan adanya perubahan yang perlu diupayakan secara bersama-sama. Kebutuhan ini mendorong masyarakat untuk terus ikut dalam peningkatan kapasitas yang dilakukan oleh pemerintah khususnya dalam mencapai tujuan mereka bersama.

Pengkondisian masyarakat ini kemudian dilanjutkan dengan peningkatan kapasitas mayarakat agar memiliki kemampuan dalam menunjang sektor kepariwisataan di Pulau Tidung ini. Peningkatan kapasitas masyarakat dilakukan dengan dua cara yakni peningkatan pengetahuan dan keterampilan. Pengetahuan mengenai perubahan yang akan dilakukan serta peluang-peluang usaha yang dapat dimanfaatkan masyarakat. Pemerintah mulai melakukan berbagai macam peningkatan keterampilan masyarakat dalam mengolah makanan, mengelola sampah dan menjaga kebersihan, serta keterampilan wisata air seperti snorkling, diving, dll. Berdasarkan hal tersebut masyarakat mulai terbiasa untuk mematuhi nilai-nilai baru yang muncul, antara lain etos kerja untuk mencapai visi dan misi bersama yaitu menjadi daerah wisata unggulan yang menjadi tujuan utama dari destinasi wisatawan.

\section{Langkah Kedua : Pengembangan Jaringan Kreatif dan Kooperatif antar actor dalam Pengelolaan Wisata}

Upaya sosialisasi dari pemerintah yang membuahkan kesadaran akan kepentingan bersama dari masyarakat pulau Tidung, menggerakkan motivasi masyarakat untuk melakukan kerjasama dan usaha-usaha kreatif. Ragam usaha yang ada di Pulau Tidung seperti usaha penginapan, usaha catering, penyewaan 
sepeda, penyewaan tenda, penyewaan perlengkapan menyelam, penyewaan perahu, jasa pemandu, serta usaha permainan air. Usaha-usaha ekonomi tersebut muncul dari kreatifitas masyarakat Pulau Tidung sendiri, dengan kata lain pesmilik usaha pada umumnya merupakan masyarakat asli Pulau Tidung. Hanya sedikit usaha yang dimiliki oleh investor yang berasal dari luar Pulau Tidung. Berkembangnya usaha pariwisata di masyarakat Pulau Tidung, dapat terjadi karena masyarakat Pulau Tidung memiliki sifat mau belajar. Umumnya mereka belajar dari masukan yang disampaikan oleh wisatawan yang pernah datang ke Pulau Tidung. Seperti misalnya mengenai layanan kamar/penginapan, wisatawan banyak yang memberikan saran mengenai pelayanan kamar yang baik dan memuaskan. Sebelumnya, pelayanan kamar di Pulau Tidung masih jauh dari standar layanan wisata. Kamar tidak memiliki fasilitas seperti pendingin ruangan, tv layar datar, kamar mandi yang seadanya, maupun kasur busa. Dari masukan dan keluhan wisatawan tersebut, maka masyarakat sedikit demi sedikit mulai membenahi fasilitas kamar penginapan untuk wisatawan. Saat ini, hampir semua kamar penginapan memiliki layanan kamar setara dengan hotel bintang satu, seperti kamar mandi dengan kloset duduk, pendingin ruangan, tv layar datar, serta kasur pegas.

Usaha-usaha kreatif masyarakat ini kemudian membuka mata masyarakat untuk membangun jejaring dengan usahawan dari luar pulau Tidung terutama agen-agen wisata yang berada di Jakarta Pusat. Agen-agen wisata ini memiliki peranan penting untuk mempromosikan pulau Tidung sebagai destinasi wisata melalui promosi di internet dan membuat paket-paket wisata yang menarik bagi wisatawan. Untuk menyentuh berbagai kalangan wisatawan, untuk paket wisata ke pulau Tidung dibuka tiga rute perjalanan menuju pulau Tidung yang menentukan fasilitas dan harga. Dengan harga dan fasilitas yang variatif ini diharapkan semakin banyak wisatawan yang akan datang mengunjungi Pulau Tidung. Sebagai contoh paket perjalanan dengan Ferry yang berangkat dari Muara Angke memiliki harga yang lebih rendah dibandingkan dengan paket perjalanan wisata dengan speed boat dari Pantai Marina Ancol.

Semakin banyaknya wisatawan yang datang, mendorong masyarakat untuk terus belajar mengenai bagaimana memberikan pelayanan yang baik bagi wisatawan. Masyarakat lokal kemudian membentuk asosiasi wisata yang menjadi payung pelaksanaan bisnis masyarakat lokal di Pulau Tidung baik dalam hal penginapan, wisata air, katering dan lain sebagainya.

\section{Langkah Ketiga: Keterlibatan Praktisi dalam Pengembangan Kawasan Wisata}

Praktisi dalam penelitian ini dapat di pilah dalam tiga kategori antara lain masyarakat, pemerintah, dan organisasi non pemerintah (baik organisasi laba maupun nirlaba). Masyarakat menjadi titik sentral dalam pengembangan pariwisata, karena masyarakat yang akan merasakan secara langsung manfaat dari berkembangnya industri 
pariwisata di daerahnya. Selain itu, tidak dapat dilepaskan peran dari pemerintah daerah dalam memberikan dukungan dan fasilitasi kepada masyarakat untuk mengembangkan potensi alam di daerahnya. Peran pemerintah dapat dilihat dari arah pembangunan yang mengedepankan potensi lokal. Salah satunya adalah melalui program pengembangan budidaya perikanan yang bersinergi dengan pariwisata. Hal tersebut dilihat dari beberapa indikator antara lain : tingginya ketergantungan masyarakat terhadap sumber daya laut dan pesisir; tingginya permintaan perikanan; rendahnya penguasaan teknologi budidaya; kualitas perairan yang layak (feasible) untuk budidaya; dan luasnya wilayah perairan untuk budidaya.

Selain dari pembelajaran masyarakat, pengembangan usaha ekonomi di sektor pariwisata tersebut juga tidak dapat dilepaskan dari peran pemerintah daerah Kabupaten Administrasi Kepulauan Seribu yang mengembangkan kebijakan dan program yang mendukung pariwisata. Kebijakan dan program tersebut merupakan turunan dari visi dan misi yang disusun oleh pemerintah daerah. Adapun visi pembangunan Kabupaten Administratif Kepulauan Seribu yaitu Ladang dan Taman Kehidupan Bahari yang Berkelanjutan.

Pemerintah daerah Kabupaten Adminsitrasi Kepulauan Seribu juga menunjukkan komitmen pengembangan pariwisata dengan membangun infrastruktur pendukung. Pemerintah membangun dan merenovasi dermaga-dermaga yang ada di pulau-pulau tujuan wisata dan pulau pemukiman. Pemerintah juga menyediakan layanan transportasi antar pulau gratis untuk memudahkan perpindahan orang serta perputaran uang antar pulau. Di Pulau Tidung misalnya, pemerintah selain membangun dermaga baru, juga merenovasi jembatan penghubung antara Pulau Tidung Besar dan Pulau Tidung Kecil. Belakangan, jembatan tersebut dikenal dengan sebutan Jembatan Cinta, dan menjadi ikon Pulau Tidung. Pemerintah juga membangun akses jalan di pulau, dengan menggunakan paving block dan diperuntukkan untuk sepeda.

Selain itu, terdapat pula upaya-upaya yang muncul dari masyarakat itu sendiri. Salah satu bentuk upaya yang dilakukan oleh masyarakat Pulau Tidung adalah dengan membentuk lembaga-lembaga lokal. Lembaga lokal yang bergerak di bidang pariwisata yang berasal dari masyarakat adalah Asosiasi Pariwisata Pulau Tidung (APPTI). Asosiasi tersebut selain bergerak sebagai perkumpulan para pengusaha atau penyedia layanan jasa pariwisata, juga berfungsi sebagai koperasi yang mengatur layanan pariwisata masyarakat. Penentuan harga tiket kapal penyeberangan serta penentuan batas harga maksimal dan minimal penginapan masyarakat, menjadi bagian dari kewenangan asosiasi tersebut. Besaran harga tiket kapal ojek yang ditetapkan oleh asosiasi yaitu sebesar Rp 37.000 
perorang. Meskipun hal tersebut masih menjadi perdebatan di kalangan pelaku usaha pariwisata, akan tetapi hal ini menjadi indikasi bahwa adanya inisiatif untuk mengorganisasikan diri yang muncul dari masyarakat.

Berdirinya asosiasi pariwisata tersebut menunjukkan adanya lembaga lokal yang terkait dengan pengembangan pariwisata. Asosiasi tersebut dapat dikategorikan sebagai lembaga lokal yang juga organisasi lokal. Hal ini dilihat dari hasil lapangan bahwa asosiasi pariwisata tersebut sudah berkembang dan sudah melembaga di masyarakat.

Selain itu, asosiasi ini juga didukung oleh lembaga lokal lain yang ada di masyarakat, seperti Lembaga Musyawarah Kelurahan (LMK) Pulau Tidung. Keberadaan asosiasi tersebut dipandang memiliki fungsi kontrol dalam pengembangan pariwisata di Pulau Tidung. Asosiasi juga akan memperkuat para pelaku jasa wisata di Pulau Tidung, sehingga akan membantu ketika muncul persoalan-persoalan di masyarakat. Jika merujuk pada pandangan Esman dan Uphoff, lembaga-lembaga lokal yang ada di masyarakat tersebut memiliki peran antara lain membantu menyediakan informasi yang akurat mengenai kondisi dan kebutuhan masyarakat, terlibat dalam kegiatan pembangunan yang dirancang pemerintah daerah, memobilisasi sumber daya manusia yang ada di masyarakat, serta pemeliharaan dan pemanfaatan fasilitas atau infrastruktur yang mendukung pariwisata.
Dari asosiasi tersebut dapat diketahui mengenai karakter masyarakat di Kepulauan Seribu, yang secara umum tidak dapat dilepaskan dari karakter masyarakat nelayan. Begitu pula dengan masyarakat di Pulau Tidung, yang mayoritas merupakan masyarakat nelayan. Masyarakat nelayan memiliki karakter yang berbeda dengan masyarakat pertanian. Dimana, masyarakat nelayan cenderung memiliki sifat instan, karena mereka terbiasa dengan sistem mencari/menangkap ikan untuk memenuhi kebutuhan hidupnya sehari-hari. Berbeda dengan masyarakat petani, yang harus melalui proses panjang untuk memenuhi kebutuhan hidupnya, yang dimulai dari penyiapan lahan sampai memanen.

Melihat karakter tersebut, dalam upaya pengembangan pariwisata di Kepulauan Seribu, pemerintah daerah menetapkan industri pariwisata bahari sebagai bagian dari visi dan misi pemerintah. Terutama misi tentang mewujudkan pariwisata kepulauan yang berkualitas dan berkelanjutan. Kebijakan pemerintah daerah tersebut sejalan dengan program pariwisata nasional. Kepulauan Seribu sejak tahun 2015 dicantumkan dalam Kawasan Strategis Pariwisata Nasional (KSPN) oleh Kementerian Pariwisata Republik Indonesia.

Kebijakan tersebut, akan menimbulkan perubahan sosial di masyarakat terutama perubahan pada kebiasaan masyarakat. Dari masyarakat nelayan, berubah menjadi 
masyarakat pariwisata. Perilaku dan kebiasaan masyarakat nelayan, sangat bertolak belakang dengan perilaku dan kebiasaan masyarakat pariwisata. Hal tersebut tentunya tidak mudah, akan tetapi pemerintah daerah berkomitmen untuk membantu masyarakat supaya mereka siap untuk menghadapi perubahan tersebut. Dukungan pemerintah dapat dilihat dari program-program pembangunan yang diarahkan untuk pengembangan industri pariwisata, seperti salah satunya pendirian koperasi simpan pinjam berbasis komunitas. Koperasi tersebut akan membantu perubahan perilaku masyarakat, dari masyarakat yang instan ke arah masyarakat yang menjalani proses. Selain itu, pemerintah juga mulai mengembangkan program perikanan tambak bagi masyarakat nelayan tangkap. Program ini secara tidak langsung juga akan membantu penyesuaian perubahan perilaku masyarakat, dari masyarakat nelayan ke masyarakat pariwisata. Jika dikaitkan dengan misi yang dicanangkan oleh pemerintah daerah, maka program-program yang dikembangkan tersebut akan mewujudkan masyarakat nelayan moderen yang berbasis pariwisata.

Selain itu, pemerintah daerah juga meyakini bahwa keterlibatan masyarakat menjadi salah satu faktor yang mempengaruhi pencapaian misi pembangunan daerah. Pelibatan masyarakat dalam pembangunan pariwisata di Kepulauan Seribu tersebut, dapat dilihat dari penempatan masyarakat sebagai aktor utama dalam pembanguan pariwisata.
Pemerintah daerah terus menerus memberikan pemahaman kepada masyarakat bahwa kondisi alam yang indah tersebut merupakan milik (aset) masyarakat, sehingga yang akan mengelola dan mendapatkan manfaat dari pengelolaan tersebut adalah masyarakat itu sendiri. Peran pemerintah hanya pada fasilitasi dan dukungan kepada masyarakat.

Hal ini juga disadari oleh masyarakat, khususnya masyarakat di Pulau Tidung. Sejak tahun 2008, masyarakat Pulau Tidung secara perlahan mulai bertransformasi dari masyarakat nelayan menjadi masyarakat wisata. Satu persatu rumah tinggal masyarakat berubah menjadi penginapan (homestay), dan sekarang sudah banyak penginapan mandiri (resort) yang dibangun oleh masyarakat. Selain penginapan, masyarakat juga sudah banyak yang beralih profesi, dimana mereka tidak lagi mengandalkan hasil laut sebagai mata pencahariannya. Masyarakat mulai merintis profesi sebagai pemandu wisata, pengelola wahana wisata, dan juga usahausaha turunan lainnya seperti pemilik penginapan (resort), usaha makanan, souvenir, maupun jasa layanan lainnya.

Industri pariwisata yang tumbuh di masyarakat tersebut, secara langsung membawa pada perubahan tingkat pendapatan masyarakat. Meskipun tingkat pendapatan dari hunian langsung bervariasi, akan tetapi ketika dirata-ratakan, pendapatan masyarakat untuk homestay berkisar di angka Rp. 450.000,- per bulan. Selain dari penginapan, pendapatan 
masyarakat juga diperoleh dari jasa angkutan antar pulau, yang rata-rata mencapai $\mathrm{Rp}$. 1.500.000,- per bulan. Sedangkan, pendapatan dari jasa lain seperti guide dan penyewaan sepeda mencapai Rp. 700.000 per bulan. Tentunya hal tersebut dapat menjadi landasan untuk mengembangkan sektor pariwisata di Pulau Tidung. Pengembangan tersebut dapat dilakukan secara terpadu antara pemerintah, masyarakat, dan swasta. Pengembangan tersebut seperti penambahan kapasitas homestay, penyediaan infrastruktur, peningkatan tenaga kerja, dan jasa lainnya. Sehingga jumlah wisatawan yang berkunjung, sekitar 293 orang per hari, akan terus mengalami peningkatan.

Pendapatan dari sektor pariwisata tersebut dapat menjadi sumber penghasilan tambahan bagi masyarakat nelayan. Dari hasil tangkapan seperti ikan tongkol, kembung, kurisi, dan cumi, rata-rata pendapatan yang diperoleh nelayan tidak lebih dari Rp. 55.000,per hari terguntung pada musim angin. Jadi dalam satu bulan jika dirata-ratakan, pendapatan nelayan kurang lebih mencapai Rp. 1.500.000,-. Dengan demikian, apabila masyarakat nelayan memaksimalkan potensi yang ada (dari sektor perikanan dan pariwisata), rata-rata penghasilan yang akan diperoleh setiap bulannya mencapai antara $\mathrm{Rp}$. 3.000.000,- sampai Rp. 5.000.000,--

Selain peningkatan pendapatan, industri pariwisata juga membawa pada perubahan perilaku masyarakat. Dimana, masyarakat menjadi semakin peduli menjaga lingkungan sekitarnya. Lingkungan yang bersih dan tertata tentunya akan memiliki nilai jual tersendiri bagi wisatawan. Demikian pula dengan pemeliharaan terumbu karang, yang menjadi tempat tinggal ikan-ikan hias. Terumbu karang yang terawat dan populasi ikan hias yang besar menjadi daya tarik bagi wisatawan yang mengambil paket wisata air seperti snorkeling.

Selain upaya yang muncul dari masyarakat, dapat dilihat pula peran yang dilakukan oleh pemerintah daerah dalam pengembangan industri pariwisata. Dukungan dan fasilitasi yang dilakukan pemerintah daerah antara lain adalah pembangunan infrastruktur (jalan, dermaga, jembatan, dan transportasi laut), peningkatan sumber daya manusia (pelatihan dan pendampingan), sampai dengan dukungan kebijakan.

Dengan demikian dapat dilihat bahwa pengembangan pariwisata di Pulau Tidung dapat berjalan dengan baik ketika masyarakat ditempatkan sebagai aktor utama. Penempatan masyarakat ini berarti bahwa keterlibatan masyarakat menjadi tujuan utama dalam pengembangan industri pariwisata. Pelibatan ini dilihat dari program-program pembangunan yang diarahkan untuk meningkatkan kapasitas masyarakat, sehingga masyarakat memiliki kemampuan untuk mengembangkan potensi yang mereka miliki.

Aktor ketiga yang terlibat dan memiliki peranan penting dalam perkembangan 
pariwisata di Pulau Tidung adalah lembaga swasta. Antara lain perusahaan yang melaksanakan CSR seperti Koran Kompas, Tempo, dan Pertamina. Lembaga penerbitan dalam hal ini memiliki fokus untuk meningkatkan skill dari masyarakat untuk menguasai bahasa Inggris. Meskipun sulit untuk mengajak masyarakat untuk berbicara bahasa Inggris dengan fasih, namun masyarakat pulau Tidung mulai bisa untuk berbicara dalam bahasa Inggris untuk percakapan sederhana dengan wisatawan asing. Sementara itu perusahaan BUMN seperti pertamina memberikan pelatihan pemeliharaan dan konservasi terumbu karang, sehingga keindahan terumbu karang di Pulau Tidung dapat terjaga dengan baik dan menjadi daya tarik bagi wisatawan asing maupun domestik yang ingin menikmati keindahan di dasar laut.

\section{Penutup}

Pengembangan pariwisata berbasis masyarakat diakui masyarakat dapat meningkatkan kesejahteraan hidup mereka, terutama dalam memenuhi kebutuhan dan peningkatan terhadap berbagai system sumber penghidupan seperti pendidikan, ekonomi, maupun kesehatan. Di antara keberhasilan pelaksanaan community practice tersebut terdapat beberapa tantangan yang harus dipikirkan bersama oleh seluruh actor di Pulau Tidung, antara lain dampak negatif dari pariwisata, seperti misalnya minuman keras, maupun prostitusi terselubung. Masyarakat pada akhirnya menjadi permisif meskipun pada awalnya melakukan penolakan terhadap dampak negatif dari pariwisata tersebut. Beragam upaya dilakukan oleh masyarakat untuk mencegah munculnya dampak tersebut. Upaya-upaya tersebut seperti melakukan razia minuman keras, pelarangan menjual dan membawa minuman keras di pulau, mengeluarkan peraturan mengenai pasangan yang akan menginap di pulau, dan sebagainya. Akan tetapi, hal tersebut ternyata mengakibatkan penurunan jumlah wisatawan yang berkunjung ke pulau. Dan secara tidak langsung, kondisi ini mengakibatkan penurunan pendapatan masyarakat. Oleh karena itu, masyarakat kemudian mencoba untuk melakukan cara-cara lain dalam upaya pencegahan munculnya dampak negatif dari pariwisata. Cara-cara tersebut antara lain membebaskan setiap wisatawan untuk membawa minuman keras, akan tetapi dengan jumlah tertentu. Kemudian, membebaskan pasangan yang datang menginap di pulau, apakah pasangan resmi atau tidak. Hal tersebut dipahami masyarakat sebagai kondisi yang tidak dapat ditolak, sebagai dampak dari adanya pariwisata itu sendiri. Sehingga, saat ini masyarakat lebih cenderung bersikap permisif terhadap dampak negatif dari pariwisata.

\section{DAFTAR PUSTAKA}

Adamson, D. 2010. Community empowerment: Identifying The Barriers to 
"purposesful" Citizen Participation. International Journal of Sociology vol. 30 3/4, 114-126.

Adi, I. R. 2003. Empowerment, Community Development and Community Intervention. Jakarta: FE-Universitas Indonesia.

Babbie, A. R. 2005. Research Methods for Social Work. Belmont: Thomson Brooks/Cole.

Cary, L.J. 1970. Community Development As a Process. Columbia: University of Missouri Press

Dubois, Brenda. Karla Krogsrud Miley. 1992. Social Work : An Empowering Profession. Boston: Pearson Education Inc.

Glen, Andrew (1993), "Methods and Themes in Community Practice" in Butcher, H., et all (eds). Community And Public Policy. London: Pluto

Hikmat, H. 2001. Strategi Pemberdayaan Masyarakat. Bandung: Humaniora Utama Press.
Ife, J. 1995. Community Development: Creating Community Alternatives - Vision, Analysis and Practice. Melbourne: Longman.

Ife, J. 2000. Community Development: Community-Based Alternatives in Age of Globalization. Melbourne: Longman.

Ife, J. 2002. Community Development. 2nd.ed., Pearson Education Australia Pty Ltd.

Ife, Jim., F. T. 2007. Community Development : Communit-based alternatives in age of globalization. Melbourne: Longman.

Midgley, James. 1995. Social Development : The Developmental Perspective in Social Welfare. London : SAGE Publications Ltd.

Razak, Abdur. Rimadewi Suprihardjo. Pengembangan Pariwisata Terpadu di Kepulauan Seribu. Jurnal Teknik Pomits, Vol 2 No 12013. 